Correspondence

Louis Gardan

gardan@angers.inra.fr

\section{Acidovorax valerianellae sp. nov., a novel pathogen of lamb's lettuce [Valerianella locusta (L.) Laterr.]}

\author{
Louis Gardan, ${ }^{1}$ David E. Stead, ${ }^{2}$ Catherine Dauga ${ }^{3}$ and Moniek Gillis ${ }^{4}$ \\ ${ }^{1}$ INRA, UMR de Pathologie Végétale, INRA-INH-Université 42, rue G. Morel, 49071 Beaucouzé \\ cedex, France \\ ${ }^{2}$ Central Science Laboratory, Sand Hutton, York YO41 1LZ, UK \\ ${ }^{3}$ Unité des Entérobactéries, Institut Pasteur, Paris, France \\ ${ }^{4}$ Laboratorium voor Microbiologie, Universiteit Gent, Gent, Belgium
}

\begin{abstract}
Bacterial spot disease of lamb's lettuce [Valerianella locusta (L.) Laterr.] was first observed in fields in 1991. This new bacterial disease is localized in western France in high-technology field production of lamb's lettuce for the preparation of ready-to-use salad. Nineteen strains isolated in 1992 and 1993 from typical black leaf spots of naturally infected lamb's lettuce were characterized and compared with reference strains of Acidovorax and Delftia. The pathogenicity of the 19 strains was confirmed by artificial inoculation. Biochemical and physiological tests, fatty acid profiles, DNA-DNA hybridization and other nucleic acid-based tests were performed.

A numerical taxonomic analysis of the 19 lamb's lettuce strains showed a single homogeneous phenon closely related to previously described phytopathogenic taxa of the genus Acidovorax. DNA-DNA hybridization studies showed that the lamb's lettuce strains were $91-100 \%$ related to a representative strain, strain CFBP $4730^{\top}$, and constituted a discrete DNA hybridization group, indicating that they belong to the same novel species. Results from DNA-rRNA hybridization, 16S rRNA sequence analysis and fatty acid analysis studies confirmed that this novel species belongs to the $\beta$-subclass of the Proteobacteria and, more specifically, to the family Comamonadaceae and the genus Acidovorax. The name Acidovorax valerianellae sp. nov. is proposed for this novel taxon of phytopathogenic bacteria. The type strain is strain CFBP $4730^{\top}\left(=\right.$ NCPPB $\left.4283^{\top}\right)$.
\end{abstract}

Lamb's lettuce, also known as corn salad [Valerianella locusta (L.) Laterr.], was traditionally cultivated in France for use in salads in autumn and winter. Since 1985, advanced technology has been used for continuous, yearround cultivation; $90 \%$ of French production (representing $75 \%$ of world production) is concentrated in western France, near the Atlantic coast. The lettuce produced is used for sale traditionally, in trays, and for the preparation of ready-to-use salad alone or mixed with other salad leaves in sealed plastic bags (Péron \& Rees, 1998).

The advanced technology of cultivation of lamb's lettuce has changed the profile of plant disease, since it has created microclimatic conditions more favourable for the development of disease. Diseases due to fungi, e.g. Peronospora valerianellae and Phoma valerianellae, remain important (Péron \& Rees, 1998).

Published online ahead of print on 18 October 2002 as DOI 10.1099/ ijs.0.02404-0.

The EMBL accession number for the $16 \mathrm{~S}$ rDNA sequence of strain CFBP $4730^{\top}$ is AJ431731.

An expanded version of Fig. 3 including more reference taxa is available as supplementary material in IJSEM Online.
In 1991, water-soaked spots that became black after 3-4 days were observed on cotyledons and leaves of crops in western France. Bacteria were consistently isolated from water-soaked spots. The pathogenicity of the strains was confirmed by artificial spray leaf inoculations. The bacterium was initially identified as a non-fluorescent Pseudomonas sp. (Rat \& Gardan, 1993; Rat et al., 1994).

The present study was initiated to make a formal description of this novel phytopathogenic group of bacteria, based on phenotypic and physiological tests, fatty acid profiles, DNA-DNA and DNA-rRNA hybridization and $16 \mathrm{~S}$ rRNA sequence analysis. Our conclusion is that this group of strains represents a novel species within the genus Acidovorax, for which the name Acidovorax valerianellae sp. nov. is proposed.

A collection of 19 strains were isolated from naturally infected plants in 1992 and 1993 from samples taken in different plots of cultivation of lamb's lettuce over a large area in western France, where around 2000 ha are grown. Reference strains included in this study are listed in Table 1. All the strains were grown at $25^{\circ} \mathrm{C}$ on YBGA $(0.7 \%$ yeast extract, $0.7 \%$ bactopeptone, $0.7 \%$ glucose and $1.5 \%$ agar; $\mathrm{pH} 7 \cdot 3$ ) (Gardan et al., 2000). 
Table 1. Strains used in this study

\begin{tabular}{|c|c|c|}
\hline $\operatorname{Strain}(\mathrm{s})$ as received & Other designation & Host plant/origin, place and year of isolation \\
\hline Acidovorax anthurii NCPPB $4104^{\mathrm{T}}$ & CFBP $3232^{\mathrm{T}}$ & Anthurium sp. (hybrid), Martinique, 1991 \\
\hline Acidovorax avenae subsp. cattleyae NCPPB $961^{\mathrm{T}}$ & CFBP $2423^{\mathrm{T}}$ & Unknown orchid, USA, 1961 \\
\hline Acidovorax avenae subsp. citrulli NCPPB $3679^{\mathrm{T}}$ & CFBP $4459^{\mathrm{T}}$ & Citrullus lanatus, USA, NK \\
\hline Acidovorax delafieldii DSM $64^{\mathrm{T}}$ & & NK \\
\hline Acidovorax konjaci NCPPB $3698^{\mathrm{T}}$ & CFBP $4460^{\mathrm{T}}$ & Amorphophallus konjaci, Japan? \\
\hline Delftia acidovorans NCPPB 1967 & & Pharyngeal swab, 1966 \\
\hline Delftia acidovorans NCPPB 1968 & & NK, 1966 \\
\hline
\end{tabular}

NK, Not known.

For pathogenicity tests, bacterial suspensions adjusted to approx. $5 \times 10^{8}$ c.f.u. $\mathrm{ml}^{-1}$ were applied on the adaxial and abaxial parts of the leaves by rubbing the leaf surfaces with a piece of sterile cotton wetted with bacterial suspension. Plants were used at the fifth to sixth leaf stage and were maintained under high relative humidity $(\geqslant 90 \%)$ in plastic tunnels.

The 20 classical biochemical and physiological tests and 147 carbon-assimilation sources used were those enumerated by Gardan et al. (2000). In total, 167 characteristics were included in the numerical taxonomy analysis. A distance matrix was calculated using the Jaccard coefficient (Sneath \& Sokal, 1973). Cluster analysis was done using UPGMA.
A total of 100 fatty acid profiles were prepared for 10 strains isolated from $V$. locusta and from representative strains of Acidovorax species with validly published names and known to cause plant disease, together with Delftia acidovorans, Acidovorax facilis and Acidovorax delafieldii (Table 2). These were all from the National Collection of Plant-Pathogenic Bacteria (NCPPB) and comprised almost all the Acidovorax and Delftia strains in the collection. They are not listed in Table 1. Cells were harvested from trypticase soy broth agar plates grown for $24 \mathrm{~h}$ at $28^{\circ} \mathrm{C}$. Replicate runs were made for some strains to ensure that differences in the profiles were not due to problems with reproducibility. Fatty acids were extracted as methyl esters by using methods described elsewhere (Stead, et al., 1992;

Table 2. Fatty acids detected in selected Acidovorax and Delftia species

Species: 1, A. valerianellae sp. nov. (10 strains analysed/10 profiles obtained); 2, A. anthurii (2/9); 3, A. avenae subsp. avenae (28/35); 4, A. avenae subsp. cattleyae (1/4); 5, A. avenae subsp. citrulli (5/11); 6, A. delafieldii (1/10); 7, A. facilis (1/5); 8, A. konjaci (4/7); 9, D. acidovorans $(2 / 2)$. Values are mean percentages \pm SD of the total named peak area.

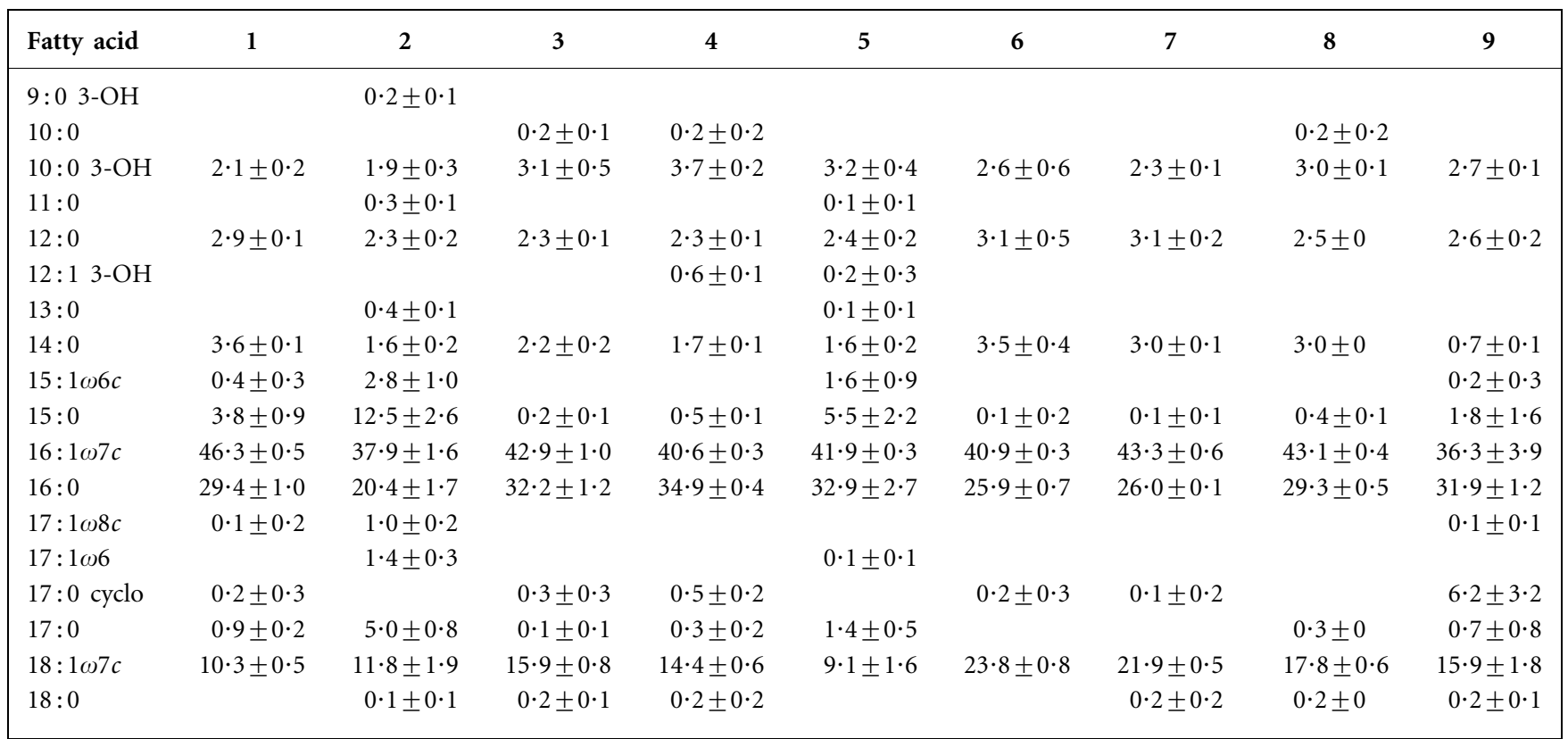


Stead, 1992a, b). Fatty acid methyl ester profiles were obtained by GC (model 6890 gas chromatograph; Hewlett Packard). Peaks were named and quantified using the Microbial Identification System (MIDI). Only profiles with total peak areas of $>50000 \mathrm{U}$ were accepted, to avoid problems of dilution. Profiles of selected strains were compared by principal component analysis and by dendrogram analysis based on UPGMA and expressed as Euclidean distances.

Extraction of DNA and DNA-DNA hybridization were done as indicated by Gardan et al. (2000). Native DNA of two lamb's lettuce strains, CFBP $4730^{\mathrm{T}}$ and CFBP 4723 , was labelled with tritiated nucleotides (Amersham) by nick-translation. The S1 nuclease/trichloroacetic acid method was used as indicated by Gardan et al. (2000). The reassociation temperature was $70^{\circ} \mathrm{C}$.

The DNA-rRNA hybridization method of De Ley \& De Smedt (1975) was used. ${ }^{3} \mathrm{H}$-labelled rRNA from Acidovorax avenae subsp. avenae NCPPB $1011^{\mathrm{T}}$ was used. Since the lamb's lettuce strains were related by phenotypic characteristics to the other phytopathogenic Acidovorax species and subspecies, we verified the assignment of the lamb's lettuce strains to the branch of $A$. avenae within the family Comamonadaceae.

16S rRNA gene (rDNA) fragments were generated by a PCR and the amplified products were then purified, cloned and sequenced (Gardan et al., 2000). Multiple sequence alignment and phylogenetic analysis were performed as previously described (Gardan et al., 2000).

\section{Pathogenicity tests}

The pathogenicity of the 19 strains was confirmed on young plants of lamb's lettuce, based on the presence of symptoms recorded for 2 weeks after inoculation. The typical water-soaked spots appeared after 3 days incubation, becoming grey to black after 6 days. The leaf spots are circular with a regular margin and can reach $3 \mathrm{~mm}$ in diameter. They can also be surrounded by a bright-yellow halo. Pathogenicity was confirmed for all 19 strains. We observed some slight variations in aggressiveness (number of leaf spots per plant), which were probably due to the method of inoculation. We demonstrated that the lamb's lettuce strains were not pathogenic to anthurium. Pure cultures were easily reisolated, especially from the watersoaked lesions. On YBGA, colonies are white/cream, circular with a clearer margin and reach diameters of 1-2 mm after 4 days incubation at $25^{\circ} \mathrm{C}$. A clear brown pigment can diffuse around the colonies after 10 days.

\section{Biochemical and physiological tests}

A dendrogram displaying the distance relationships amongst the 23 strains is shown in Fig. 1. At a distance of $0 \cdot 12$, the 19 lamb's lettuce strains were clustered in one phenon. The small distance $(0 \cdot 12)$ of clustering for the lamb's lettuce strains indicated a highly similar phenotypic

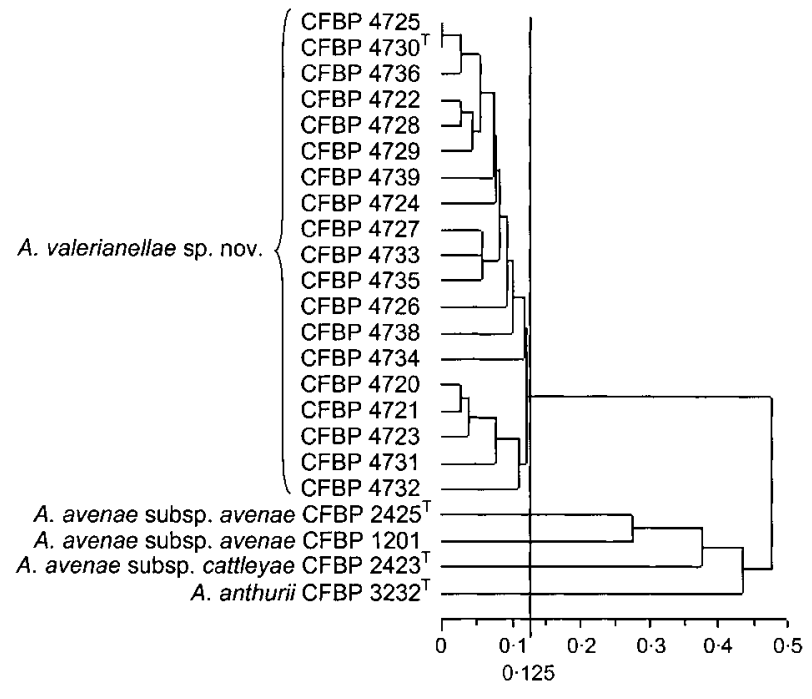

Fig. 1. Dendrogram obtained using UPGMA of distances of the Jaccard coefficient, among 32 strains tested from Acidovorax valerianellae sp. nov., Acidovorax, Burkholderia, Herbaspirillum and Pseudomonas.

profile, demonstrating that they constitute a phenotypically homogeneous group of strains.

Gardan et al. (2000) indicated the phenotypic characteristics that differentiate the lamb's lettuce strains from phytopathogenic Acidovorax species and other species of Acidovorax. Four additional biochemical tests can be used to distinguish the lamb's lettuce strains from Acidovorax anthurii. The lamb's lettuce strains assimilate sebacate and tryptophan but do not assimilate D-arabitol or DL-5aminobutyrate. The reverse responses are obtained for A. anthurii.

\section{Fatty acid extraction and analysis}

All strains from $V$. locusta gave very similar profiles. All strains contained 3-hydroxydecanoic acid $(10: 03-\mathrm{OH})$, which was the only hydroxy fatty acid present in the profile. All strains also contained dodecanoic acid (12:0), tetradecanoic acid (14:0), pentadecanoic acid $(15: 0)$, hexadecanoic acid $(16: 0)$, cis-9-hexadecenoic acid $(16: 1 \omega 7 c)$, heptadecanoic acid (17:0) and cis-11-octadecenoic acid $(18: 1 \omega 7 c)$. In addition, some strains contained small amounts of cis-9-pentadecenoic acid $(15: 1 \omega 6 c)$, cis-9,10methylene hexadecanoic acid $(17: 0$ cyclo) and cis-9heptadecenoic acid $(17: 1 \omega 8 c)$. Fatty acid data for all plant-pathogenic Acidovorax species and some other Acidovorax species and $D$. acidovorans are shown in Table 2. The $V$. locusta profiles were very similar to each other, and standard deviations divided by mean values were $<0.56$ for all fatty acid methyl esters present in all strains. The proportions of $10: 03-\mathrm{OH}$ and $18: 1 \omega 7 c$ in the profiles of the $V$. locusta strains were generally smaller than for almost all other taxa, while the proportions of 
$14: 0,15: 0$ and $16: 1 \omega 7 c$ were generally greater than for other taxa (Table 2). These results show that the profiles were typical of the genus Acidovorax and of D. acidovorans in having 3-hydroxydecanoic acid as the major hydroxy acid (Oyaizu \& Komagata, 1983; Willems et al.,1990; Stead, 1992a; Gardan et al., 2000.) In fact, whereas some other Acidovorax taxa have traces of other hydroxy acids, 3-hydroxydecanoic acid was the sole hydroxy acid in the lamb's lettuce strains tested. Although there were no fatty acids unique to the $V$. locusta strains, quantitative differences supported genomic data favouring a novel taxon. Dendrogram analysis of strains of most taxa included in the study (Fig. 2) also showed a discrete cluster within 4 Euclidean distance units of each other, but which was 7 Euclidean distance units away from other taxa. Principal component analysis (not presented) showed that the 10 $V$. locusta strains formed a discrete homogeneous cluster. Fatty acid analysis provided phenotypic support for differentiation of all taxa included in the study. The two strains of $A$. anthurii clustered separately in both analyses. These analyses also showed that the proposed type strain $\left(\mathrm{CFBP} 4730^{\mathrm{T}}\right)$ is a typical member of the panel of strains.

\section{DNA-DNA hybridization}

Results of DNA hybridization studies are shown in Table 3. Eleven of 19 lamb's lettuce strains from the phenon (derived from phenotypic analysis) in which all

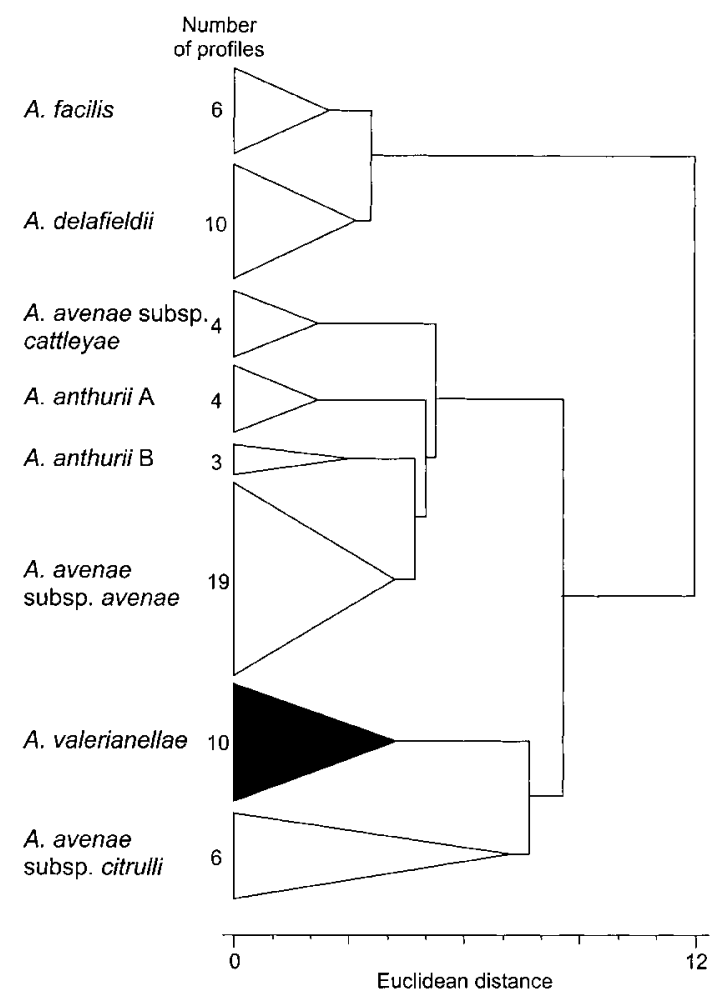

Fig. 2. Clustering of Acidovorax valerianellae sp. nov. and related strains by fatty acid profiling.
Table 3. Levels of DNA relatedness among Acidovorax valerianellae sp. nov. and related strains

Hybridization was determined at $70{ }^{\circ} \mathrm{C}$. ND, Not determined.

\begin{tabular}{|c|c|c|}
\hline \multirow[t]{2}{*}{ Source of unlabelled DNA } & \multicolumn{2}{|c|}{$\begin{array}{l}\text { Relative binding with } \\
\text { labelled DNA from: }\end{array}$} \\
\hline & $\begin{array}{l}\text { CFBP } \\
4730^{T}\end{array}$ & $\begin{array}{l}\text { CFBP } \\
4723\end{array}$ \\
\hline \multicolumn{3}{|l|}{ A. valerianellae sp. nov. } \\
\hline CFBP $4730^{\mathrm{T}}$ & 100 & 91 \\
\hline CFBP 4720 & 100 & 100 \\
\hline CFBP 4721 & 84 & 100 \\
\hline CFBP 4723 & 100 & 100 \\
\hline CFBP 4725 & 100 & 98 \\
\hline CFBP 4726 & 95 & 99 \\
\hline CFBP 4728 & 89 & 88 \\
\hline CFBP 4731 & 100 & 100 \\
\hline CFBP 4732 & 100 & 93 \\
\hline CFBP 4733 & 92 & 89 \\
\hline CFBP 4734 & 100 & 100 \\
\hline A. anthurii CFBP $3232^{\mathrm{T}}$ & 24 & $\mathrm{ND}$ \\
\hline \multicolumn{3}{|l|}{ A. avenae subsp. avenae } \\
\hline CFBP $2425^{\mathrm{T}}$ & 19 & ND \\
\hline CFBP 1201 & 23 & ND \\
\hline A. avenae subsp. cattleyae CFBP $2423^{\mathrm{T}}$ & 35 & ND \\
\hline A. avenae subsp. citrulli CFBP $4459^{\mathrm{T}}$ & 29 & ND \\
\hline A. konjaci CFBP $4460^{\mathrm{T}}$ & 15 & ND \\
\hline
\end{tabular}

the lamb's lettuce strains clustered are $84-100 \%$ (mean $99 \cdot 7 \%$, SD 8.8 ) related to CFBP $4730^{\mathrm{T}}$. The same strains were $91-100 \%$ related to CFBP 4723 (mean 96.5\%, SD $5 \cdot 8$ ). Thus, the lamb's lettuce strains are members of a single DNA hybridization group.

Representative strains of the phytopathogenic species A. anthurii, Acidovorax konjaci and three subspecies of A. avenae were $15-35 \%$ related to strain CFBP $4730^{\mathrm{T}}$. Seven strains of Burkholderia sp., one strain of Herbaspirillum and four strains of non-fluorescent Pseudomonas sp. were very distantly related $(0-5 \%)$ to strain CFBP $4730^{\mathrm{T}}$ (data not shown). Other non-phytopathogenic Acidovorax species were not included in this study because they belong to another rRNA branch. Thus, the lamb's lettuce strains constitute a discrete genomospecies.

\section{DNA base composition}

The $\mathrm{G}+\mathrm{C}$ content of the DNA was determined from the thermal denaturation temperature as described by Gardan et al. (2000). The G $+\mathrm{C}$ content of strain CFBP $4730^{\mathrm{T}}$ was found to be $64.5 \mathrm{~mol} \%$.

\section{DNA-rRNA hybridization}

The $\Delta T_{\mathrm{m}}(\mathrm{e})$ values of two strains tested, CFBP 4723 and CFBP $4730^{\mathrm{T}}$, were respectively $1 \cdot 3$ and $1 \cdot 6^{\circ} \mathrm{C}$, and showed that these strains belong to the Acidovorax rRNA branch. 
They were more closely related to A. avenae subsp. avenae than to A. konjaci, which had a $\Delta T_{\mathrm{m}}(\mathrm{e})$ of $3 \cdot 1{ }^{\circ} \mathrm{C}$. We could assign the lamb's lettuce strains to the genus Acidovorax within the family Comamonadaceae, in the $\beta$-subclass of the Proteobacteria sensu Stackebrandt et al. (1988), and to superfamily III sensu De Ley (1978).

\section{$16 S$ rRNA sequencing and sequence analysis}

A total of 1492 nucleotides of $16 \mathrm{~S}$ rDNA sequence of strain CFBP $4730^{\mathrm{T}}$ were determined. Phylogenetic sequence analysis confirmed the affiliation of the newly isolated strains to the genus Acidovorax (Fig. 3). Our sequence branched in the vicinity of $A$. anthurii regardless of the phylogenetic method used. These sequences were included in a cluster of phytopathogens, A. avenae subsp. avenae, subsp. citrulli and subsp. cattleyae and A. konjaci, described previously (Wen et al., 1999) (Fig. 3; an expanded tree is available as supplementary material in IJSEM Online). This tree topology was confirmed by using a maximumparsimony method (data not shown). The maximumlikelihood analysis led to a different topology, in which A. avenae subsp. avenae, subsp. citrulli and subsp. cattleyae rooted the newly described $A$. anthurii phylogenetic group (data not shown).

The similarity values calculated for the $16 \mathrm{~S}$ rDNA sequences of the novel Acidovorax isolate and its closest relatives (A. avenae subsp. avenae, subsp. citrulli and subsp. cattleyae and $A$. anthurii) ranged from $97 \cdot 6$ to $98 \cdot 4 \%$. Because of the microheterogeneity of $16 \mathrm{~S}$ rRNA genes within species, these similarity values cannot be used for delimiting species (Rossello-Mora \& Amann, 2001). However, DNA relatedness levels showed unambiguously that the lamb's lettuce strains constitute a novel species.

On the basis of pathogenicity tests, phenotypic properties,

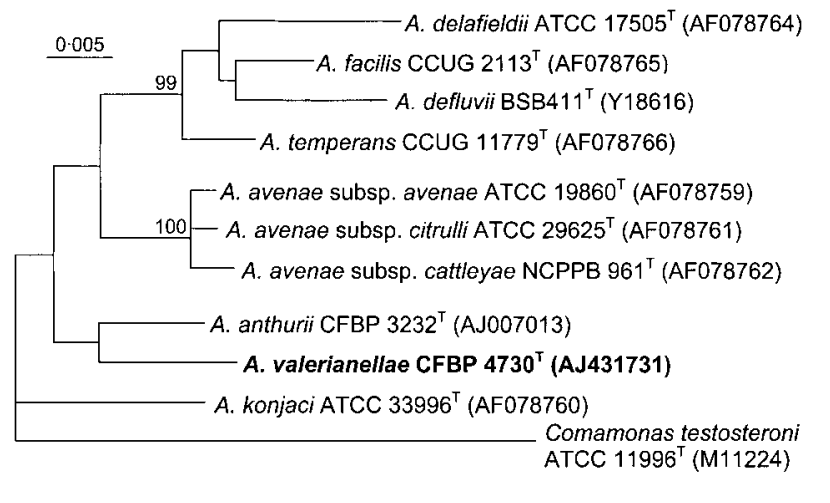

Fig. 3. Neighbour-joining tree obtained from 16S rRNA gene sequences. The scale bar represents 1 estimated base substitution per 200 nucleotide positions. Percentages refer to bootstrap values of 100 calculated trees. EMBL/GenBank accession numbers are shown in parentheses. An expanded version of this tree, showing more taxa, is available as supplementary material in IJSEM Online. fatty acid profiles, DNA-DNA reassociation values, $16 \mathrm{~S}$ rDNA sequencing, DNA-rDNA hybridization and G $+\mathrm{C}$ content, the lamb's lettuce strains should be considered as a novel species of the genus Acidovorax. The name Acidovorax valerianellae sp. nov. is proposed.

\section{Description of Acidovorax valerianellae sp. nov.}

Acidovorax valerianellae (va.le.ri.a.nel'lae. N.L. fem. gen. n. valerianellae of Valerianella, the genus name of lamb's lettuce, the host plant).

On YBGA, colonies are slow-growing, $2 \mathrm{~mm}$ in diameter after 4 days incubation, circular, slightly raised and white/ cream with a clear margin. Cells are Gram-negative, straight rods, motile by means of a long polar flagellum. Oxidase, catalase and urease tests are positive. Strictly aerobic: there is no anaerobic acid production from glucose in a Hugh and Leifson test. Poly- $\beta$-hydroxybutyrate is accumulated. Nitrates are not reduced and arginine, gelatin and aesculin are not utilized. No growth at 4 or $41{ }^{\circ} \mathrm{C}$. Glycerol, D-fructose, gluconate, succinate, fumarate, glutarate, adipate, pimelate, suberate, azelate, sebacate, DL-lactate, DL-3-hydroxybutyrate, D-malate, L-malate, pyruvate, 2-ketoglutarate, L-alanine, L-leucine, L-isoleucine, L-phenylalanine, L-tyrosine, L-histidine, L-tryptophan, L-aspartate, L-glutamate, L-proline and DL-4-aminobutyrate are assimilated. All strains possess 3-hydroxydecanoic acid, which is the only hydroxy fatty acid present. Many other carbon sources are not utilized. All strains elicit a hypersensitive reaction on tobacco leaves and are pathogenic on V. locusta, producing leaf-spot symptoms.

The type strain is strain CFBP $4730^{\mathrm{T}}\left(=\mathrm{NCPPB} 4283^{\mathrm{T}}\right)$. The $\mathrm{G}+\mathrm{C}$ content of the DNA of the type strain is $64.5 \mathrm{~mol} \%$ (thermal denaturation method).

\section{Acknowledgements}

We thank Andy Aspin, John Heeney, Solange Belouin and Alain Huard for technical assistance.

\section{References}

De Ley, J. (1978). Modern molecular methods in bacterial taxonomy: evaluation, application, prospects. In Proceedings of the International Conference on Plant Pathogenic Bacteria, vol. 1, pp. 347-357. Tours: Gilbert.

De Ley, J. \& De Smedt, J. (1975). Improvements of the membrane filter method for DNA:rRNA hybridization. Antonie van Leeuwenhoek 41, 287-307.

Gardan, L., Dauga, C., Prior, P., Gillis, M. \& Saddler, G. S. (2000). Acidovorax anthurii sp. nov., a new phytopathogenic bacterium which causes bacterial leaf-spot of anthurium. Int $J$ Syst Evol Microbiol 50, 235-246.

Oyaizu, H. \& Komagata, K. (1983). Grouping of Pseudomonas species on the basis of cellular fatty acid composition and the quinone system with special reference to the existence of 3-hydroxy fatty acids. J Gen Appl Microbiol 29, 17-40. 
Péron, J. Y. \& Rees, D. C. (1998). High-tech production of corn salad (Valerianella locusta (L.) Laterr.), a local, French vegetable crop. Acta Hortic 467, 259-268.

Rat, B. \& Gardan, L. (1993). La tache bactérienne due à un Pseudomonas sp. Fruits Légumes 11, 42-43.

Rat, B., Gardan, L. \& Bollet, C. (1994). Black spot of lamb lettuce: a new bacterial disease. In Plant Pathogenic Bacteria, p. 183. Edited by M. Lemattre, S. Freigoun, K. Rudolph \& J. G. Swing. Paris: INRA.

Rossello-Mora, R. \& Amann, R. (2001). The species concept for prokaryotes. FEMS Microbiol Rev 25, 39-67.

Sneath, P. H. A. \& Sokal, R. R. (1973). Numerical Taxonomy: Principles and Practice of Numerical Classification. San Francisco: W. H. Freeman.

Stackebrandt, E., Murray, R. G. E. \& Trüper, H. G. (1988). Proteobacteria classis nov., a name for the phylogenetic taxon that includes the "purple bacteria and their relatives". Int J Syst Bacteriol 38, 321-325.

Stead, D. E. (1992a). Grouping of plant-pathogenic and some other Pseudomonas spp. by using cellular fatty acid profiles. Int J Syst Bacteriol 42, 281-295.
Stead, D. E. (1992b). Techniques for detecting and identifying plant pathogenic bacteria. In Techniques for Rapid Diagnosis of Plant Pathogens, pp. 76-111. Edited by J. Duncan \& L. Torrance. Oxford: Blackwell Science.

Stead, D. E., Sellwood, J. E., Wilson, J. \& Viney, I. (1992). Evaluation of a commercial microbial identification system based on fatty acid profiles for rapid, accurate identification of plant pathogenic bacteria. J Appl Bacteriol 72, 315-321.

Wen, A., Fegan, M., Hayward, C., Chakraborty, S. \& Sly, L. I. (1999). Phylogenetic relationships among members of the Comamonadaceae, and description of Delftia acidovorans (den Dooren de Jong 1926 and Tamaoka et al. 1987) gen. nov., comb. nov. Int J Syst Bacteriol 49, 567-576.

Willems, A., Falsen, E., Pot, B., Jantzen, E., Hoste, B., Vandamme, P., Gillis, M., Kersters, K. \& De Ley, J. (1990). Acidovorax, a new genus for Pseudomonas facilis, Pseudomonas delafieldii, E. Falsen (EF) group 13, EF group 16, and several clinical isolates, with the species Acidovorax facilis comb. nov., Acidovorax delafieldii comb. nov., and Acidovorax temperans sp. nov. Int J Syst Bacteriol 40, 384-398. 